\title{
Drafting and Interpreting International Investment Agreements from a Sustainable Development Perspective
}

Claudia Salgado Levy*

DOI: $10.21827 / 5 a 86 a 8818 a a e b$

\section{Keywords}

INVESTMENT TREATY ARBITRATION; INVESTMENT TREATY INTERPRETATION; Sustainable Development; Investment Policy Making; Systemic Treaty INTERPRETATION

\begin{abstract}
The proliferation of International Investment Agreements (IIAs) and treaty-based investment arbitration has raised concerns over the extent to which IIAs are actually fair and are able to balance the interests of foreign investors and States. The strong protections afforded by IIAs to investors may restrict the host State's ability to regulate for the public interest and potentially allow newly adopted public policies to be subject to compensation.

Several economic transactions that have qualified as investments for treaty protection have fallen short of contributing to the host State's sustainable development. They have not added to the generation of employment and growth, the transfer of new technologies and knowledge or the strengthening of infrastructure. Nor have many of these economic transactions contributed to the home country's development. Moreover, regulatory measures adopted with the aim of fostering sustainable development (ie environmental measures) have been successfully challenged by investors. In some cases tribunals have interpreted these measures as creeping or indirect expropriations, therefore requiring compensation.

Both the lack of consideration for the host State's interests under international investment law and the limitation to the State's policy space have been perceived as having negative implications for the development of the country, and in particular for the adoption of sustainable policies. Though little empirical evidence exists, it has been suggested that investment arbitration is a threat to the adoption of public policy regulations and may even have a 'chilling effect' on them.

A possible way forward is the negotiation of a new generation of investment treaties, as well as the renegotiation and revision of the existing ones. These changes are needed in order to balance the interests of States and investors and to incorporate innovative features in light of the necessary policy space that States require in order to foster sustainable development through the application of dynamic social and environmental norms and regulations. Another alternative is the adoption of interpretative approaches, which ultimately foster sustainable development goals. The preferred options are the contextual and dynamic interpretation of the intention of the contracting States, as well as the systemic integration of international rules and norms into investor-State disputes.
\end{abstract}

$\mathrm{PhD}$ candidate at the Graduate Institute of International and Development Studies (2010-2015), Geneva-Switzerland. E-mail: claudia.salgado@graduateinstitute.ch. The views expressed in this paper are those of the author and do not necessarily reflect those of the Institute. 


\section{Introduction}

The international investment regime is an emerging and rapidly evolving field of international law. ${ }^{1}$ It is essentially constituted of a large number of International Investment Agreements (IIAs) negotiated over the last five decades. IIAs tend to resemble each other in their structure and content. They also pursue the same objective of protecting foreign investments and investors from the illegal actions of host States through the establishment of certain rules and standards of treatment.

One of the most important features of investment treaties is that they provide foreign investors access to international arbitration for the settlement of investment disputes. This mechanism has led to an explosion of international investor-State dispute settlement (ISDS) cases. Indeed, the total cumulative number of known treaty-based cases filed by the end of 2013 surpassed $560 .^{2}$

The proliferation of cases has given rise to several concerns. The increasing number of proceedings not only runs the risk of developing inconsistencies and incoherence in international investment law regime, ${ }^{3}$ but it also creates the perception that IIAs are devices that can immunise investors from the compliance of bona fide social and environmental laws and regulations. ${ }^{4}$ Indeed, foreign investors have used the protection afforded by IIAs to challenge newly enforced public policy measures, requesting the suspension of the measure, or compensation for the losses suffered. ${ }^{5}$

Moreover, as some claim, investor-State arbitration may have a 'chilling effect' on the States' legitimate public policy initiatives and regulatory actions. ${ }^{6}$ States may become reluctant to adopt measures for environmental protection, safety and public welfare if they feel threatened by potential claims from foreign investors. All of this has raised concerns that States' efforts to pursue sustainable development (SD) objectives may be undermined by the strong treaty protections afforded to foreign investors. This might

1 Salacuse, JW, The Law of Investment Treaties (Oxford University Press, Oxford, 2010), 6-16.

2 United Nations Conference on Trade and Development (UNCTAD), REPORT: Recent Developments in Investor-State Dispute Settlement, IIA Issues Note, 1 April 2014, at <unctad.org/en/publicationslibrary/webdiaepcb2014d3_en.pdf> (accessed 17 April 2015), 1.

3 See generally Dolzer, R and Schreuer, C, Principles of International Investment Law (Oxford University Press, Oxford, 2008), 35-37.

4 Ruggie, JG, Stabilization Clauses and Human Rights, A research project conducted for IFC and the United Nations Special Representative to the Secretary General on Business and Human Rights, 11 March 2008, at $<$ cdm16064.contentdm.oclc.org/cdm/ref/collection/p266901coll4/id/2486> (accessed 17April 2015).

5 See Ethyl Corporation $v$ The Government of Canada, NAFTA/UNCITRAL, Preliminary Tribunal Award on Jurisdiction, 24 June 1998; Methanex Corporation v United States of America, NAFTA/UNCITRAL, Final Award of the Tribunal on Jurisdiction and Merits, 3 August 2005; Dow AgroSciences LLC $v$ The Government of Canada, NAFTA/UNCITRAL, Notice of Arbitration, 31 March 2009; FTR Holdings SA, Philip Morris Products SA and Abal Hermanos SA (Switzerland) v Oriental Republic of Uruguay, ICSID case No ARB/10/7, Request for Arbitration, 19 February 2010; Vattenfall AB, Vattenfall Europe AG, Vattenfall Europe Generation $A G v$ The Federal Republic of Germany, ICSID Case No ARB/09/6, Award, 11 March 2011; Vattenfall AB, Vattenfall Europe AG, Vattenfall Europe Nuclear Energy GmbH, Kernkraftwerk BrunsbüttelGmbH und Co oHG, Kernkraftwerk Krümmel GmbH und Co oHG v The Federal Republic of Germany, ICSID Case No ARB/12/12; Philip Morris Asia Limited $v$ The Commonwealth of Australia, UNCITRAL, PCA Case No 2012-12.

6 For further discussion on this issue, Moloo, R and Jacinto, J, "Environmental and Health Regulation: Assessing Liability Under Investment Treaties", 29(1) Berkeley Journal of International Law (2011) 1; See also Paparinskis, M, "Regulatory Expropriation and Sustainable Development" in Gehring, MW, Cordonnier-Segger, MC and Newcombe, A, eds, Sustainable Development In International Investment Law (Kluwer Law International, Alphen aan den Rijn, 2011), at $<$ ssrn.com/abstract=1698192> (accessed 17 April 2015). 
threaten the legitimacy of the investor-State dispute settlement system, to the detriment of States and foreign investors. Within this context, the purpose of this paper is to contribute some reflections on how to achieve the necessary protections of foreign investors while promoting States' sustainable development through investment agreements. ${ }^{7}$

To begin with, this paper makes an assessment of the current framework of investment treaty provisions from a sustainable development perspective. With this aim, the paper uses several examples, including the definition of investment, investor and expropriation. It suggests that existing treaty provisions and the interpretation given to them by arbitral tribunals fall short of assisting - and sometimes even constrain - contracting States in pursuing SD outcomes.

Second, this paper examines recent investment policy-making undertaken with the aim of fostering SD-friendly IIA clauses. In so doing, it will provide an initial review of recent State practice regarding the adoption of SD treaty provisions. Likewise, it will mention the policy options offered in UNCTAD's Investment Policy Framework for Sustainable Development (IPFSD). ${ }^{8}$

Finally, this paper argues that sustainable development objectives can also be incorporated in international investment law through the application of a 'SD-oriented interpretation' within the context of investor-State dispute settlement (ISDS) cases. The judicial function of investment tribunals and the interpretative techniques rooted in customary international law offer ample justifications and entry points for the adoption of such an interpretative approach.

\section{The Current Framework of International Investment Law and Sustainable Development}

At present, more than 3,200 IIAs have been concluded with the purpose of promoting and protecting foreign investments. ${ }^{9}$ Over time, a series of concerns have emerged regarding today's multi-faceted and multi-layered network of treaties. ${ }^{10}$

First, investment treaty provisions tend to be drafted in very general terms, usually lacking specificity and clarity. This has provided tribunals with broad interpretative discretion, allowing them to take 'expansionary views' on the scope of application and the meaning of these provisions. Through that, tribunals have contributed to a lack of predictability and certainty as well as a certain fragmentation of international investment law. Second, IIAs contain little to no straightforward references of the parties' intention to foster sustainable development goals. In some IIAs, these references are expressed vaguely or in an indirect manner. This combination of broad interpretations by arbitral

7 While SD is the overall objective and theme of this paper, an in-depth discussion on the content and meaning of sustainable development is beyond its scope. Instead, the paper uses SD as embracing the three pillars of economic development, social equity and environmental protection, as set out in the United Nations Report of the World Commission on Environment and Development (WCED) in 1987, also known as the Brundtland Report; UN General Assembly, Report of the World Commission on Environment and Development, 11 December 1987, (96th plenary meeting) A/RES/42/187.

8 United Nations Conference on Trade and Development (UNCTAD), Investment Policy Framework for Sustainable Development (July 2012) at <unctad.org/en/PublicationsLibrary/diaepcb2012d5_en.pdf> (accessed 6 May 2015) (IPFSD).

9 UNCTAD, World Investment Report 2012: Towards a New Generation of Investment Policies, 2012, at <unctad.org/en/PublicationsLibrary/wir2012_embargoed_en.pdf> (accessed 17 April 2015), 84.

10 For a full discussion of concerns see, for instance, UNCTAD, World Investment Report 2014: Investing in the SDGs: An Action Plan, at <unctad.org/en/PublicationsLibrary/wir2014_en.pdf> (accessed 17 April 2015), Chapter III.B. 
tribunals and weak references to SD, together with strong substantive and procedural protections given to foreign investors, has resulted in the concern that IIAs can be detrimental to countries' broader SD goals.

In the following section, this paper reviews a few examples of where tribunals have adopted wide, inconsistent and even contradictory interpretations to the requirements ratione personae, materiae and, in terms of procedural aspects, disregarded what States had intended to see applied in ISDS cases. Arbitral tribunals have upheld jurisdiction over disputes that States might never have envisaged as being the subject of arbitration, or found violations of provisions for regulatory actions long perceived to be outside the realm of IIAs. In many instances, this has touched upon issues of great relevance for countries' SD objectives.

\section{II.1. Broad Interpretation of the Definition of Investment}

One of the most important IIA provisions is the clause setting out the scope and definition of investment.

Through this provision, signatory countries determine which investments benefit from the treaty's protection. IIA treaty practice varies, with the two most important choices embraced by States being the asset-based definition and the enterprise-based definition of investment. Both, as open-ended approaches, have favoured a broad definition of investment. $^{11}$

One recurring issue relates to the question whether IIAs should only protect - and hence attract - responsible or sustainable development enhancing investment (eg. investments that generate employment, transfer new technologies, strengthen infrastructure or build knowledge). Alternatively, should IIAs be a tool to protect (or attract) any kind of foreign capital and at any cost for the host State?

The open-ended approach to treaty drafting and the extensive interpretations adopted by arbitral tribunals have given rise to developments that may have an adverse effect on countries' sustainable development objectives. First, treaty protection has been extended to transactions that have fallen far short of contributing to the host State's economic growth. Second, treaty protection has been granted to investments that have disregarded the host State's national laws and regulations, resulting in a situation where illegal investments have benefitted from treaty protection. Both situations will be further explained.

\section{II.1.1. Does any Transaction Qualify as Investment?}

In theory, States conclude investment treaties to attract foreign direct investments (FDI), which is a potential vehicle for the transfer of technology and can contribute relatively more to growth than domestic investment. ${ }^{12}$ However, not every economic transaction may be qualified as an investment, nor should be protected by investment treaties.

Many economic transactions fall far short of stimulating broad-based economic growth or generating the necessary linkages required to make FDI work for sustainable economic development. ${ }^{13}$ In fact, simple sales transactions, purchases of goods and short-

11 UNCTAD, REPORT: Scope and Definition: A sequel, Series on Issues in International Investment Agreements II, 2011, at<unctad.org/en/Docs/diaeia20102_en.pdf> (accessed 17 April 2015), 21.

12 Borensztein, E, de Gregorio, J and Lee, J-W, "How does foreign direct investment affect economic growth?”, 45 Journal of International Economics (1998) 115.

13 Gallagher, $\mathrm{K}$ and Chudnovsky, D, eds, Rethinking Foreign Investment for Sustainable Development: Lessons from Latin America (Anthem Press, London, 2010). 
term commercial credits do not contribute to development of the host State since they do not help generate employment, nor do they provide knowledge, transfer of skills or technology to the local community. Furthermore, these transactions may not even have any return to the home country.

The case Patrick Mitchell $v$ Democratic Republic of Congo (DRC) was an attempt to categorise a legal counselling firm as an investment. The arbitral tribunal decided that a US national, who had operated a small law firm in the DRC, was an investment. However an ad hoc committee annulled this arbitral award because the original tribunal had 'manifestly exceeded its power' and had failed to State its reasons for finding that $\mathrm{Mr}$ Mitchell had made 'investments' covered under the relevant investment treaty and the ICSID Convention. ${ }^{14}$

In Malaysian Historical Salvors $v$ the Government of Malaysia,${ }^{15}$ the sole arbitrator held that although the contract did provide some benefit to Malaysia there was not a sufficient contribution to Malaysia's economic development to qualify as an 'investment' for purposes of Article 25(1) of the Convention. Nonetheless, the annulment committee had an opposing view and considered that the sole arbitrator limited itself to the analysis of the requirements under the Convention, but failed to apply the bilateral investment treaty, which has a broad definition of the term investment. Moreover, the annulment committee considered that the investment made by the Malaysian Historical Salvors was a contribution that had cultural and historical value to the country. ${ }^{16}$

Although ICSID decisions do not constitute precedent, and ICSID tribunals are not bound by previous decisions, several tribunals have coincided with the identification of some features required for an investment to qualify as a covered investment: 1 . It must have certain duration and a regularity of profit and return; 2 . There must be an assumption of risk involved, usually by both sides; 3 . There must be a commitment; and 4. The economic operation must have significance for the host State's development. ${ }^{17}$ These features are now known as the 'Salini test'.

Some tribunals have applied this test to determine whether the requirement of having an investment in the host State is satisfied. ${ }^{18}$ Nonetheless, other tribunals have

14 Patrick Mitchell v Democratic Republic of Congo, ICSID Case No AERB/99/7, Award, 9 February 2004; Patrick Mitchell v Democratic Republic of Congo, ICSID Case No AERB/99/7, Decision on the Application for Annulment of the Award, 1 November 2006.

15 The Malaysian Historical Salvors (MHS) was a marine salvage outfit owned by a British national that retrieved thousands of pieces of Chinese porcelain from the Straight of Malacca in the 1990's. In contract with Malaysia, the company was to receive a portion of the proceeds from the sale of the treasure; however, MHS maintained that it received a smaller cut of the profits than was promised under the contract. For more information, see International Institute for Sustainable Development, Investment Treaty News, at <iisd.org/itn> (accessed 17 April 2015).

16 Malaysian Historical Salvors, SDN, BHD $v$ The Government of Malaysia, ICSID Case No ARB/05/10, Annulment Decision, 16 April 2009.

17 Salini Costruttori SpA and Italstrade SpA v Kingdom of Morocco, ICSID Case No ARB/00/4, Decision on Jurisdiction, 23 July 2001, para 52. Some tribunals have considered that the fourth condition is included in the other three.

18 This is the formula adopted in Joy Mining Machinery Limited $v$ Arab Republic of Egypt, ICSID Case No ARB/03/11, Award on Jurisdiction, 6 August 2004; Jan de Nul NV and Dredging International NV v Arab Republic of Egypt, ICSID Case No ARB/04/13, Decision on Jurisdiction, 16 June 2006; Helnan International Hotels A/S v Arab Republic of Egypt, ICSID Case No ARB/05/19, Decision of the Tribunal on Objection to Jurisdiction, 17 October 2006; Mr Patrick Mitchell v Democratic Republic of the Congo, ICSID Case No ARB/99/7, Decision on the Application for Annulment of the Award, 1 November 2006; Saipem SpA v The People's Republic of Bangladesh, ICSID Case No ARB/05/07; Malaysian Historical 
disregarded the application of the Salini test. In particular, the Phoenix tribunal rejected the notion that a contribution to development should be criteria of an ICSID investment, on the view that development of the host State is impossible to ascertain. ${ }^{19}$ In Pey Casado $v$ Chile, the tribunal considered that the feature of contribution is in fact included in the other features of the investment, as a consequence but not a condition for, or an essential component of it. ${ }^{20}$

From the above analysis, it is worth recalling that even if the ICSID Convention is silent on the definition of the term 'investment', in its preamble it states that private international investment has a role in the international cooperation for States' economic development. Hence, ICSID tribunals should interpret 'the term investment in the light of the objectives and purposes of the Convention and take into account, explicitly or implicitly, the significance of the investment for the host State's development. The major aim of the Convention was to encourage the economic development of State parties by way of foreign investment.

Through investment treaties, contracting States can provide specific rules and definitions as well as additional requirements for purposes of granting jurisdiction to ICSID tribunals. However, they cannot oppose, disregard or extend the Convention's requirements because it is the Convention which sets the general framework for ICSID Jurisdiction. As Prosper Weil stated

it is within the limits determined by the basic ICSID Convention that the BITs may determine the jurisdiction and powers of the ICSID tribunal, and it is not for the Contracting Parties in their BIT to extend the jurisdiction of the ICSID tribunal beyond the limits determined by the basic ICSID Convention. ${ }^{21}$

\section{II.1.2. Should Investment Treaties Protect Illegal Investments?}

Due to broad interpretations, treaty protection has been extended in one way or another to investments which have been operated by willful misrepresentation, fraud, in bad faith, or in violation of national or international public policy.

The fact that 'illegal' investments are protected by IIAs is detrimental to SD because it may convey the message that foreign investors are not expected to respect and comply with the laws and regulations of the host State in areas such as labour, antitrust, human rights and environmental laws. Also, investments made through corrupted practices have a direct and pernicious effect on the economic development of countries, notably so in developing countries. ${ }^{22}$

In Occidental v Ecuador, the tribunal found that the investors breached a clause of the participation contract by purporting to transfer rights under the contract without the required ministerial authorisation. As a consequence to the contractual breach, the Minister of Energy and Mines declared the termination (caducidad) of the contract. The

Salvors, SDN, BHD v The Government of Malaysia, ICSID Case No ARB/05/10, Award on Jurisdiction, 17 May 2007.

19 Phoenix Action Ltd. $v$ The Czech Republic, ICSID Case No ARB/06/5, Award, 15 April 2009, para 85.

20 Victor Pey Casado and President Allende Foundation v Republic of Chile, ICSID Case No ARB/98/2, Award, 8 May 2008, para 232.

21 Tokios Tokeles v Ukraine, ICSID Case No ARB/02/18, Decision on Jurisdiction, 29 April 2004, (Dissenting Opinion, Weil P) para 13.

22 F-W Oil Interests Inc $v$ The Republic of Trinidad and Tobago, ICSID Case No ARB/01/14, Award, 3 March 2006, para 212. 
tribunal qualified the investors' conduct as a 'wrongful act', 'negligence', 'grave mistake' and 'unlawful act'. ${ }^{23}$ Furthermore, since the investors did not seek nor obtain the required authorisation, the tribunal found that investors acted negligently and committed an unlawful act which contributed in a material way to the prejudice which the investors subsequently suffered when the contract was terminated. ${ }^{24}$ Through these findings, the tribunal concluded that by committing this 'material and significant wrongful act' investors only contributed $25 \%$ of the prejudice which they suffered when the Ministry adopted the punitive measure (termination of the contract). ${ }^{25}$ The dissenting arbitrator was of the view that 'the consequence of the fault committed by the Claimants, when they violated the Ecuadorian law, was overly underestimated and insufficiently taking into account the importance that each and every state assigns to the respect of its legal order by foreign companies. ${ }^{26}$

Notwithstanding the Occidental v Ecuador case, it appears to be an emerging consensus that illegal investments should not be protected by investment treaties and, in particular, by the investor-State dispute settlement mechanism. Several investment tribunals have dealt with investors' misconduct and have acknowledged that investors' illegal behaviour may have an international legal effect and may be taken into account during an arbitration proceeding.

In Saluka v Czech Republic the tribunal recalled that investments must have been made in accordance with the provisions of the host State's laws, and that unlawful investments were not entitled to protection under the treaty. ${ }^{27}$ Similar conclusions were reached in Salini Costruttori SpA and Italstrade SpA v Kingdom of Morocco ${ }^{28}$ and in Tokios Tokelés $v$ Ukraine. $^{29}$

The tribunal in LESI $S p A$ et Astaldi $S p A v$ Algeria stated that investments made in violation of fundamental governing principles lose their protection. ${ }^{30}$ Along the same lines, the tribunal in Rumeli Telekom $v$ Kazakhstan recalled that in order to receive the protection of a bilateral investment treaty, the disputed investments have to be in conformity with the host State's laws and regulations and that investments in the host State will only be excluded from the protection of the treaty if they have been made in breach of fundamental legal principles of the host country. ${ }^{31}$

Other important cases under which investments were not protected by the ISDS mechanism due to their illegal character are Inceysa Vallisoletana SL v Republic of El Salvador ${ }^{32}$ and Fraport AG Frankfurt Airport Services Worldwide v Republic of the Philippines. ${ }^{33}$

23 Occidental Petroleum Corporation and Occidental Exploration and Production Company $v$ The Republic of Ecuador, ICSID Case No ARB/06/11, Award, 5 October 2012, paras 662-692.

24 Occiendental v Ecuador, paras 679-680.

25 Occiendental $v$ Ecuador, para 687.

26 Occidental Petroleum Corporation and Occidental Exploration and Production Company $v$ The Republic of Ecuador, ICSID Case No ARB/06/11, Dissenting Opinion Stern B, para 4.

27 Saluka Investments BVv The Czech Republic, UNCITRAL, Partial Award, 17 March 2006, paras 204, 217.

$28 I d$, para 46.

29 Tokios Tokelés v Ukraine, paras 84-85.

30 LESI SpA et Astaldi SpA v République Algérienne Démocratique et Populaire, ICSID Case No ARB/05/3, Decision, 12 July 2006 (translated from French), para 83.

31 See also, Plama Consortium Limited v Republic of Bulgaria, ICSID Case No ARB/03/24, Award, 27 August 2008; Alasdair Ross Anderson et al v Republic of Costa Rica, ICSID Case No ARB(AF)/07/3, Award, 19 May 2010; Philippe Gruslin v Malaysia, ICSID Case No ARB/99/3, Award, 27 November 2000; Phoenix Action v Czech Republic; Gustav FW Hamester GmbH and Co KG v Republic of Ghana, ICSID Case No ARB/07/24, Awards, 18 June 2010.

32 Inceysa Vallisoletana SL v Republic of El Salvador, ICSID Case No ARB/03/26, Award, 2 August 2006. 
Yet, several scholars as well as investment tribunals have suggested that investor's conduct should more frequently influence the award of monetary damages. For instance, in MTD Chile $S A v$ Republic of Chile, the tribunal reduced by half the damages that were awarded to the claimant because of his own behaviour. ${ }^{34}$

Thus, the above cases suggest that due consideration should be given to the legality requirement of the investment. A balanced approach is needed between the promotion and protection of investments and the investor's duty to comply with the substantive legal framework during the admission process of the investment as well as its lifespan. Fostering investors' compliance with domestic laws and fundamental principles as well as with the proper standards to conduct their business is positive from the perspective of SD. ${ }^{35}$

\section{II.2. Broad Interpretation of the Definition of Investor}

Another important IIA provision is the clause setting out the scope and definition of 'investors'. Through this provision signatory countries determine which foreign investors benefit from the treaty's protection. Treaty practice varies in the criteria used for determining the nationality of legal entities, ie the country of organisation or incorporation, the country of the seat or the country of ownership or control. In many cases, IIAs use a combination of criteria. ${ }^{36}$

Investment treaties which only adopt the test of the place of constitution or incorporation as the criteria to define foreign investors may be misused. For instance, nationals of a contracting State may incorporate an entity in the other contracting State and then bring back the assets as protected foreign investments, so as to take advantage of the protection against their own country. ${ }^{37}$ Equally, investors may incorporate an entity in third countries with the aim to acquiring the protection of investment treaties that they would not otherwise have in their home State's jurisdiction. These situations are known as treaty shopping and round-tripping. ${ }^{38}$

Several issues merit attention in this regard. First, the potential abuses of the 'corporate nationality' and, in general, treaty shopping may result in host States becoming the object of claims by 'mailbox companies'. ${ }^{39}$ Second, the contracting parties' intention is circumvented by investors' operating through shell companies. Third, these shell companies do not have a real link or substantial business activity in their place of incorporation, and hence do not contribute to the home State's economic development.

Tribunals have adopted broad interpretations on these issues in a series of cases, for example, the following. In Tokios Tokelés $v$ Ukraine the tribunal decided that, although it was $99 \%$ owned and two thirds managed by Ukrainian nationals, the company Tokios Tokelés was a Lithuanian national. It reached this conclusion by interpreting the

33 Fraport AG Frankfurt Airport Services Worldwide $v$ The Republic of the Philippines, ICSID Case No ARB/03/25, Award, 16 August 2007: Award was annulled by the Decision on the application for annulment, 23 December 2010; however, the issue about the illegality of the investment was not subject of further analysis by the ad hoc committee.

34 MTD Equity Sdn Bhd And MTD Chile SA v Republic of Chile, ICSID Case No ARB/01/7, Award, 25 May 2004.

35 Further issues on legality of the investment are dealt with below.

36 UNCTAD, Scope and Definition, supra nt 10, 81.

37 Id, 15.

38 Sornarajah, M, "The Retreat of Neo-Liberalism in Investment Treaty Arbitration" in Rogers, CA and Alford, RP, eds, The Future of Investment Arbitration (Oxford University Press, Oxford, 2009), 279.

39 UNCTAD, Scope and Definition, supra nt 10, xiii. 
ordinary meaning of the terms contained in the definition of investor under the bilateral treaty. ${ }^{40}$

As a consequence of the interpretation, in accordance with the ordinary meaning of the words, the tribunal found itself competent to resolve a dispute that was ultimately between the host State and its own nationals, who were able to benefit from the ISDS mechanism through the creation of a foreign subsidiary. This decision did not take into account the objective and purpose of either the ICSID Convention or the UkraineLithuania bilateral investment treaty. The ICSID Convention was meant for promoting private international investment and settling disputes between a contracting State and nationals of the other contracting State. ${ }^{41}$ The Convention is thus in a peculiar situation, as it neither covers disputes between two governments (since these disputes may be brought to the International Court of Justice or the Permanent Court of Arbitration), nor disputes between States and their own nationals, since they may be brought to domestic courts or domestic arbitration. ${ }^{42}$

In Saluka v Czech Republic, the tribunal agreed that Saluka had no real connection with the State party to the investment treaty and that it was a mere shell company under Japanese ownership. It also acknowledged the disadvantages of the formalistic test, in particular the risk for treaty shopping, but concluded that it cannot impose upon the parties a definition of 'investor' other than that which they themselves have agreed. ${ }^{43}$

In a more recent case, Abaclat et al $v$ Argentina, the tribunal held that securities entitlements acquired by claimants in secondary securities markets outside Argentina were investments. According to the dissenting opinion,

the ... case is ... the first one to come before an ICSID tribunal in which the alleged investment is totally free-standing and unhinged, without any anchorage, however remote, into an underlying economic project, enterprise or activity in the territory of the host state. None of the logical short-cuts put forward by the majority award to palliate this absence, holds water. ${ }^{44}$

The above cases illustrate the broad interpretations given to the investor's definition. It is important to note that through investment treaties, contracting parties aim to protect their investors when investing abroad. A strong reason for doing so is that both parties benefit from this foreign investment. On the one hand, from the perspective of a capital importing country, investments can contribute to its economic development, ie by generating employment, transferring new technologies, infrastructure and knowledge. On the other hand, from the capital-exporting perspective, its national investors will increase their profits abroad and hence will contribute to the economy of the home country, ie by paying taxes and repatriating profits as well as the home country's balance of payments.

40 Tokios Tokelés $v$ Ukraine.

41 Preamble, International Center for Settlement of Investment Disputes, Convention on the Settlement of Investment Disputes between States and Nationals of Other States (2006) 575 UNTS 159.

42 Schreuer, C, The ICSID Convention: A Commentary (2nd ed, Cambridge University Press, Cambridge, 2009), 25.

43 Saluka v Czech Republic, para 229.

44 Abaclat and Others $v$ Argentina, ICSID Case No ARB/07/5, Decision on Jurisdiction and Admissibility, 4 August 2011; Abaclat and Others $v$ Argentina, ICSID Case No ARB/07/5, Dissenting Opinion AbiSaab, G), 28 October 2011, para 118. 
Abuses on the part of investors and treaty shopping diminish the common will of the contracting States. Treaty shopping disregards the fact that treaties are negotiated based on each party's needs and strengths, and also that treaties contain their own internal balance. As Professor Stern has mentioned, it looks like we are 'walking towards a general system of compulsory arbitration involving states for all matters relating to international investments. ${ }^{45}$

It might be the case that a State concludes an investment treaty with another State in order to attract investors from that State because of a specific reason. This could include the fact that the home State has strong environmental laws and regulations, and therefore its nationals have already developed environmental friendly technology, or because national investors already comply with certain standards regulated by their home States, even if investing abroad. However, by treaty shopping, including the use of the most favoured nation's treatment clause, several provisions of the main treaty may be disregarded (ie, clauses on denial of benefits as well as the definition of investment and investor).

\section{II.3. Broad Interpretation of the Expropriation Clause}

Another key IIA clause is the one on expropriation. As part of their regulatory power, States have the right to expropriate. The idea behind the expropriation clause on investment treaties is to protect foreign property and investments from States' measures that detrimentally affect them. Investment treaties only regulate the conditions that need to be met for the expropriation of foreign property. If these conditions are met, including an appropriate compensation, the expropriation is considered lawful and the State does not engage in international responsibility.

However, tribunals have stated that expropriation

includes not only open, deliberate and acknowledged takings of property, such as outright seizure or formal or obligatory transfer of title in favour of the host State, but also covert or incidental interference with the use of property which has the effect of depriving the owner, in whole or in significant part, of the use or reasonably-to-be-expected economic benefit of property even if not necessarily to the obvious benefit of the host State. ${ }^{46}$

While direct expropriations have been easy to identify, indirect expropriations have been the object of debate and discrepancy amongst investment tribunals as well as host States. Drawing the line between an indirect expropriation and a bona fide non-regulatory measure adopted for public interest has been, in practice, very difficult.

The perception that general regulatory measures adopted for public interest may be challenged as de facto takings, and thus may require compensation, have raised grave concerns. States may be discouraged or unwilling to adopt new public regulations. Their ability to regulate in favour of health, environment and human rights is then affected and restrained. This limitation to the regulatory space of States can reduce States' ability to

45 Stern, B, "ICSID Arbitration and the State's Increasingly Remote Consent: Apropos the Maffezini Case" in Charnovitz, S, Steger, DP and Van den Bossche, P, eds, Law in the Service of Human Dignity: Essays in Honour of Florentino Feliciano (Cambridge University Press, Cambridge, 2005), 259.

46 Metalclad Corporation v Mexico, ICSID Case No ARB(AF)/97/1, Final Award, 30 August 2000, para 103. 
achieve legitimate policy objectives and impede their realization of sustainable development goals.

It has been strongly debated whether 1 . Foreign investors have to bear the whole costs when a bona fide regulatory measure which nullifies their investments is adopted, ie by not being compensated even if the State measure has substantially affected their investment; and 2. Society has to bear the costs for having adopted a new regulatory measure in the society's benefit, and therefore investors get compensated. ${ }^{47}$ The answer will depend on the analysis of several issues such as whether the measure is viewed as unreasonable or discriminatory. If investors had legitimate expectations, the impact of the measure on the investment and whether there has been an unjust enrichment of the State. However, good governance, which is part of sustainable development principles, does not mean that States should compensate all and every situation where bona fide measures affect investments.

By way of illustration, it is helpful to recall few investment cases where tribunals have dealt with challenges to States' regulatory measures. In Petrobart v Kyrgyz Republic the tribunal affirmed that States, as contracting parties to investment treaties, are under the obligation to carry out reorganisation (in this case the restructuring of a system for supply of oil and gas) in a way which shows due respect to investors. ${ }^{48}$ In Marion v Costa Rica, the investor was denied the permits to develop a beachfront tourist project because the area was preserved for endangered leatherback turtles. The tribunal found that

while there can be no question concerning the right of the government of Costa Rica to expropriate property for a bona fide public purpose, pursuant to law, and in a manner which is neither arbitrary or discriminatory, the expropriatory measure must be accompanied by compensation for the fair market value of the investment. ${ }^{49}$

In SAUR v Argentina the tribunal analysed the police powers doctrine, which allows the State to adopt regulations in the public interest. The tribunal acknowledged that police power regulations impose a limitation on the freedom of foreign investors in the management, maintenance, use disposal and enjoyment of their investments. Accordingly, those policy power regulations may qualify as indirect expropriations. The tribunal also agreed that policy power regulations do not constitute a wrongful act according to customary law and that, in certain circumstances, compensation is not even necessary. 50 Nevertheless, the tribunal emphasised that, in the instant case, the investment treaty required compensation for any regulation adopted by the State in its policy powers' exercise. ${ }^{51}$

In Quasar de Valors v Russian Federation, the tribunal held that,

where the value of an investment has been substantially impaired by state action, albeit a bona fide regulation in the public interest, one can see the force in the proposition that investment protection treaties might not allow

\footnotetext{
47 Higgins, R, The Taking of Property by the State: Recent Developments in International Law (vol 176, Martinus Nijhoff Online, Leiden, 1982).

48 Petrobart Limited v Kyrgyz Republic, SCC No 126/2003, Arbitral Award, 29 March 2005, para VIII.8.9.

49 Marion Unglaube v Republic of Costa Rica, ICSID Case No ARB/08/1, Award, 16 May 2012, para 205.

50 SAUR International SA v Argentine Republic, ICSID Case No ARB/04/4, Decision on Jurisdiction and Liability, 6 June 2012, para 398.

51 Id, paras 406-407.
} 
a host State to place such a high individual burden on a foreign investor to contribute, without the payment of compensation, to the accomplishment of regulatory objectives for the benefit of a national community of which the investor is not a member. 52

Several other cases could be cited to show the difficulties of distinguishing compensable expropriations from non-compensable regulations adopted in the public interest, including for the protection of health and the environment. Yet, for purposes of the analysis, it suffices to say that findings that regulatory measures need to be compensated may preclude the adoption of legitimate regulations, and this would be detrimental for the achievement of SD goals. It is therefore necessary to balance investors' legitimate rights with the State's legitimate right to regulate. States should not lose their domestic policy space to regulate development objectives such as the incorporation of environmental provisions, corporate social responsibility norms, and human rights into their legal system.

Furthermore, treaty protection cannot be seen as a guarantee for risk-free activities on the part of investors. Foreign investment occurs within a complex and sophisticated legal framework of tax, antitrust, administrative, labour, environmental, human rights and other laws and regulations. Investors who take the decision to invest in a foreign country should be aware that there is always a risk that the legal and regulatory framework changes in the absence of assurances to the contrary. The possible changes in domestic regulatory framework and policies, such as fiscal treatment, repatriation of assets, and other State actions are in fact considered a traditional part of the political risks of investment. 53

Similar situations arise with respect to the broad interpretation given to other key treaty provisions such as most favoured nation treatment clause and the fair and equitable treatment provision. Moreover, in several investment cases the State's regulatory power has been challenged as having simultaneously breached the expropriation provision as well as other key investment treaty standards. Tribunals have applied different views and considerations to determine whether the regulatory measure has breached IIA provisions or not. The result is the same

Host states are concerned about a shrinking of domestic policy space occasioned, based on vague standards of investment protection by international arbitrators who exercise interpretative powers over the content of investment treaty obligations and who are de facto able to restrict even policy choices made by democratically elected legislators. ${ }^{54}$

Concerns that IIAs may diminish states' regulatory policy space in favor of investors' private interests has led to different reactions by states. This will be further analysed in the next section.

52 Quasar de Valors SICAV SA et a (Formerly Renta 4 SVSA et al) v Russian Federation, SCC Case No 24/2007, Award, 20 July 2012, para 23.

53 Muchlinski, P, Multinational Enterprises and the Law (2nd ed, The Oxford International Law Library, Oxford, 2007).

54 Schill, S, International Investment Law and Comparative Public Law, (Oxford University Press, New York, 2010), 7. 


\section{Fostering Sustainable Development Objectives Through Investment Policy Making}

When States negotiate IIAs they are accepting a restriction of their policy space in favour of foreign investors. However, it is not until States face a claim that they are aware of the extent to which the IIA may restrict their regulatory powers. Different reactions by States have been adopted: attempts to withdraw from the investment regime, and attempts to reform or modify it. The former manifests itself through efforts limiting States' exposure to ISDS cases; the latter through the adoption of IIAs with innovative features aimed at boosting parties' SD objectives.

In the following subsections, this paper will list several States' attempts to withdraw from the international investment regime by denouncing the ICSID Convention and investment treaties (subsection 2.1). Then, it will discuss States' willingness to achieve sustainable development objectives though the adoption of a new generation of investment treaties (subsection 2.2). The latter will give special attention to the Investment Policy Framework for Sustainable Development (IPFSD) recently adopted by the United Nations Conference on Trade and Development (UNCTAD), which is a valuable tool for the successful implementation of this new generation of investment treaties.

\section{III.1. Attempts to Limit Investment Tribunals' Jurisdiction: Withdrawing from the ICSID Convention and/or Denouncing International Investment Treaties}

The Republic of Ecuador tried to limit ICSID jurisdiction by notifying the Centre, pursuant to Article 25(4) of the ICSID Convention that it will not submit to ICSID's jurisdiction for disputes that arise in matters concerning the treatment of investments in economic activities related to the exploitation of natural resources such as oil, gas, minerals or other resources. Then, Ecuador denounced the ICSID Convention. Finally, it decided to terminate its bilateral investment treaties (BITs) by denouncing nine treaties in 2008,55 and by launching a process to analyse whether the remaining BITs, in particular their ISDS clause, were consistent with the newly adopted Constitution of 2008. The Constitutional Court of Ecuador declared the ISDS clauses contained in the BITs with Argentina, Canada, Chile, China, Finland, France, Germany Great Britain and Ireland, The Netherlands, Sweden, Switzerland, 56 the United States of America and Venezuela as unconstitutional. As a consequence of these findings, Ecuador sent a notification denouncing the BIT concluded with Finland and may do the same with other BITs. ${ }^{57}$

Bolivia also denounced the ICSID Convention as a first step to avoid investor-State arbitration. ${ }^{58}$ Furthermore, it sent a notice in 2011 to the US Government expressing its

\footnotetext{
55 BITs concluded with Cuba, Dominican Republic, El Salvador, Guatemala, Honduras, Nicaragua, Paraguay, Romania and Uruguay.

56 The BIT concluded with Switzerland in 1968 did not contain an ISDS provision, but it was also declared contrary to the Constitution because of the State-State dispute settlement provision, at $<$ corteconstitucional.gob.ec/> (accessed 27 March 2015).

57 Ibid.

58 Denunciation made in 2007.
} 
intention not to renew the Bolivia-USA BIT once it arrives towards its end. ${ }^{59}$ Likewise, Venezuela denounced in 2008 the BIT concluded with The Netherlands and is planning to renegotiate or to terminate the remaining 24 Bilateral Investment Treaties. In addition, in 2012 Venezuela withdrew from ICSID. Along the same lines, the BIT concluded between El Salvador and Nicaragua was denounced. ${ }^{60}$ And more recently, South Africa expressed its intention not to renew its BIT with the Belgium-Luxembourg Economic Union and 12 other BITs it previously entered into with other European Union (EU) Member States. 61

\section{III.2. Adoption of the New Generation of Investment Treaties}

In addition to denouncing and withdrawing from the investment system, there is the possibility to negotiate 'sustainable development enhanced' investment treaties or to renegotiate and revise the existing ones. It is worth noting that contracting States may also issue interpretative declarations in order to clarify the scope and meaning of key treaty provisions. Many countries have opted for this option and are negotiating or renegotiating agreements with some safeguards and other innovative features. Mainly, States are seeking to find a balance between the private interests of investors and the States' necessary policy space to accomplish sustainable developments goals.

It is within this context that the United Nations Conference on Trade and Development (UNCTAD) has developed an Investment Policy Framework for Sustainable Development (IPFSD). The purpose of the IPFSD is to facilitate the drafting of IIAs that create synergies with wider economic development goals, foster responsible investment and ensure policy effectiveness. This policy framework consists of a set of 11 core principles and a comprehensive list of policy options for the negotiation and design of investment treaty clauses, covering pre and post-investment establishment, qualitative aspects of investment, special and differential treatment to investors, reservations, exceptions and other concrete options. These options include provisions designed to strengthen the sustainable development dimension of the international investment policy regime, resolve issues stemming from the regime's increasing complexity and to adjust the balance between the rights and obligations of States and investors.

Examples of IIA provisions that have incorporated or reflected sustainable development related concerns are discussed below.

\section{III.2.1. Preambles with SD references}

Preamble provisions are the contracting parties' inspirational statements. They are useful for interpretation purposes. Several investment treaties have tried to include a reference, although sometimes vague, to the need of both contracting parties to pursue sustainable development objectives.

59 Network for Justice in Global Investment, The Emerging Challenge to the Investor-State Regime, 30 August 2012 at <justinvestment.org/2012/08/the-emerging-challenge-to-the-investor-state-regime-2/> (accessed 6 May 2015).

60 UNCTAD, "Denunciation of the ICSID Convention and Bits: Impact on Investor-State Claims", 2 IIA Issues Note (December 2010) 1, at <unctad.org/en/Docs/webdiaeia20106_en.pdf> (accessed 5 May 2015).

61 The notice of termination was contained in a letter entitled, "Termination of the Bilateral Investment Treaty with the Belgo-Luxembourg Economic Union", from Maite Nkoana-Mashabane, Minister of International Relations and Co-operation, to the Ambassador of the Kingdom of Belgium to South Africa, Johan Maricou, 7 September 2012. 
For example, Azerbaijan's BITs concluded with Estonia (2010) and Czech Republic (2011) state in their preamble: 'Desiring to achieve these objectives in a manner consistent with the protection of health, safety, and the environment and the promotion of sustainable development...' Similarly, the preamble of the Colombia-Japan BIT (2011) says: 'Recognizing that these objectives and the promotion of sustainable development can be achieved without relaxing health, safety and environmental measures of general application...'. The Japan-Papa New Guinea BIT (2011) also states

Recognizing that economic development, social development and environmental protection are interdependent and mutually reinforcing pillars of sustainable development and that cooperative efforts of the Contracting Parties to promote investment can play an important role in enhancing sustainable development...

\section{III.2.2. IIA's Definitions Reflecting SD Considerations:}

\section{III.2.2.1. Investment}

UNCTAD's IPFSD suggests that one option regarding the definition of investment could be to indicate that protected investments shall fulfil specific characteristics according to the parties' needs and expectations, such as delivering a positive development impact on the host country and assets acquired for the purpose of establishing a lasting economic relation (Option 2.1.2). Providing further qualifications, clarifications and explanatory notes to the term investment allows countries to attract foreign direct investment (FDI) conducive to sustainable development and to protect transactions that contracting parties consider beneficial for them.

Another option, which may be complementary to the aforementioned option, is to offer treaty coverage only to legal investments at both the admission stage (2.1.2) and during its lifespan (7.1.1). In fact, IIAs may expressly contain a provision indicating that investments must continue to function according to the laws and regulations of the host State or insisting that only foreign investment complying with these laws and regulations 'from time to time in existence' will qualify for protection. ${ }^{62}$ This requirement aims to promote investor compliance with the laws and regulations of the host State.

However, it is worth making some clarifications of the legality requirement. Investors are required to observe the substantive legal and regulatory norms of the host State, which may be applicable to their investments even if they are difficult to comprehend, such as taxation law. This does not mean that the host State can abuse its legislative power and create inconsistency or arbitrariness where rules are applied to one person, and not to another, or at one time and not another, or recognised and enforced by one organ of the State and ignored by another. But the legality requirement may not be understood to imply that foreign investments have to comply with each and every provision of domestic law or else risk forfeiture of the protection afforded by the IIA, or with norms that are strictly considered as formalities. In fact, as Professor Dolzer has stated, it would appear implausible to argue that each infraction of the local laws would deprive the investor of the guarantees laid down in an IIA.

Such a conclusion would also contradict general principles of law, such as Article 27 of the Vienna Convention, which provides that a State party may not invoke the

62 Sornarajah, M, The International Law on Foreign Investment (3rd ed, Cambridge University Press, Cambridge, 2010), 227. 
provisions of its internal law as justification for its failure to perform a treaty. ${ }^{63}$ With a very similar approach, the arbitral tribunal in Tokios Tokelés $v$ Ukraine stated that 'to exclude an investment on the basis of such minor errors would be inconsistent with the object and purpose of the Treaty.' ${ }^{64}$ Also, the Fraport $v$ Philippines tribunal recalled that in some circumstances, the law in question of the host State may not be entirely clear and mistakes may be made in good faith. ${ }^{65}$ Furthermore, to accept that overcoming the illegality of the investment will always deprive the investor from the IIA protection gives the possibility to the host State to unilaterally withdraw its commitments under the IIA towards the foreign investment by imposing new and high requirements to the investment in such a way that it would become illegal.

\section{III.2.2.2. Investor}

Regarding the definition of investors, one option that fits with SD objectives is to require investors to have their seat and substantive business activities in their home country in order to be considered as nationals of this country. Alternatively, it may be possible to include a denial of benefits clause (2.2.2) to avoid legal entities without real economic activity in their home State to benefit from IIA protection. For instance, the recently concluded Canada-China Foreign Investment Promotion and Protection Agreement (2012) contains a clause on denial of benefits which allows countries to deny benefits at any time, including after the filing of a case. The contracting parties' intention was to carve out from the definition of investor 'shell companies' owned by nationals of a thirdcountry.

Regarding the treaty practice, the USA-Uruguay BIT concluded in 2004 (which was not in force yet) was replaced by a new BIT concluded by the signatories in 2005 . Modifications were made to Article 17 (denial of benefits) and the selection of arbitrators in the settlement of disputes. In addition, for greater certainty, many explanatory notes were incorporated in the definition of investment, investment agreement, investment authorization and financial services. ${ }^{66}$ More recently, the China-Cuba BIT concluded in 1995 was modified by the parties in 2010. Amongst other amendments, parties clarified the scope and the meaning of the term 'investment' and they included a new requirement for legal entities to qualify as investors (ie entities need to conduct substantial business activities in their place of incorporation, to be considered as nationals of a contracting State).

\section{III.2.3. Standards of Protection and Treatment Clauses with SD Considerations:}

\section{III.2.3.1. Expropriation}

The right to regulate is crucial for achieving States' particular policy objectives and concerns, including sustainable development goals. The expropriation clause in IIAs is one of the clauses that may limit most States' regulatory space. That is the reason why a good option is to draft a detailed provision clarifying what constitutes indirect expropriation in order to provide guidance to tribunals, and to prevent expansive

63 Dolzer, R, and Stevens, M, Bilateral Investment Treaties, (Kluwer Law International, The Hague, 1995); Fraport AG Frankfurt Airport Services Worldwide v Republic of the Philippines, ICSID Case No ARB/03/25, Award, 16 August 2007, para 304.

64 Tokios Tokelés $v$ Ukraine, paras 83-86.

65 Fraport AG Frankfurt Airport Services Worldwide v Republic of the Philippines, para 396.

66 For further reference, Organisation of American States, Foreign Trade Information System (SICE), at <sice.oas.org> (accessed 27 March 2015). 
interpretations. It is also necessary to explain the circumstances and the criteria to determine and differentiate non compensable regulatory measures from indirect expropriation. As UNCTAD's IPFSD policy options acknowledges, it is very important to specify the standard of compensation when an expropriation has occurred.

Some clarifications of what does and does not constitute expropriation are found in the Annex III of the Colombia-Japan BIT (2011)

... 2. The determination of whether a government measure or a series of government measures of a Contracting Party, in a specific fact situation, constitutes an indirect expropriation requires a case-by-case, fact-based inquiry that considers, among other factors:

(a) the economic impact of the government measure or series of government measures, although the fact that such measure or series of such measures has an adverse effect on the economic value of investments, standing alone, does not establish that an indirect expropriation has occurred;

(b) the extent to which the government measure or series of government measures interferes with distinct and reasonable expectations arising out of investments;

(c) the character of the government measure or series of government measures, including whether such measure is non-discriminatory; and

(d) the objectives of the government measure or series of government measures including whether such measure is taken for legitimate public objectives.

3. Except in such circumstances as when a measure or a series of measures is so severe in the light of their purpose that they cannot be reasonably viewed as having been adopted and applied in good faith, non-discriminatory measures of a Contracting Party that are designed and applied to protect legitimate public welfare objectives in accordance with paragraph 1 of Article 15 do not constitute indirect expropriation.

It is worth noting that older IIAs also contain some explanations regarding indirect expropriation and some others also include exceptions and reservations in respect to health and environment. (ie Australia-Chile Free Trade Agreement (FTA) (2008); many Foreign Investment Promotion and Protection Agreements (FIPAs) signed by Canada such as Canada-Peru BIT (2006), Canada-Jordan (2009) and Canada-Slovak Republic BIT (2010); several United States FTAs such as the ones concluded with Australia (2004), CAFTADR (2004), Chile (2003) and Morocco (2004).

\section{III.2.4. Achievement of SD Objectives Through Other Treaty Provisions}

SD may be achieved through the adoption of several other treaty provisions. Contracting parties can make clear that they will preserve their right to regulate for public interest by describing situations and circumstances where treaty protection does not apply or by adopting 'defence clauses' agreeing that certain policies taken pursuant to sustainable development do not constitute treaty violations. States can also acknowledge that they 
shall not lower environmental and labour standards in order to attract foreign investments.

One such treaty example is the Korea-Peru FTA (2011), Chapter 9, Article 9.9, which states:

1. Nothing in this Chapter shall be construed to prevent a Party from adopting, maintaining, or enforcing any measure otherwise consistent with this Chapter that it considers appropriate to ensure that investment activity in its territory is undertaken in a manner sensitive to environmental concerns.

2. The Parties recognize that it is inappropriate to encourage investment by relaxing their health, safety, or environmental measures. Accordingly, $a$ Party should not waive or otherwise derogate from, or offer to waive or otherwise derogate from, such measures as an encouragement for the establishment, acquisition, expansion, or retention in its territory of an investment of an investor. If a Party considers that the other Party has offered such encouragement, the Parties shall consult, upon request, with a view to avoiding any such encouragement. ${ }^{67}$

Similarly, the India-Malaysia Comprehensive Economic Cooperation Agreement (2011), Article 10.20 , says

Measures in Public Interest: Nothing in this Chapter shall be construed to prevent: (a) a Party or its regulatory bodies from adopting, maintaining or enforcing any measure, on a non-discriminatory basis; or (b) the judicial bodies of a Party from taking any measures, consistent with this Chapter that is in the public interest, including measures to meet health, safety or environmental concerns. ${ }^{68}$

Through exceptions and exclusion clauses, States may decide to exclude from the scope of application of the treaty issues related to culture, health and the environment that are sensitive for the achievement of sustainable development. Similarly, key sectors necessary for the attainment of sustainable development may be excluded from the treaty application.

\section{III.2.5. Encouraging Anti-corruption Practices and the Corporate Social Responsibility}

In the last few decades increasing attention has been paid to anti-corruption practices and to the duties of investors towards the countries in which they invest. There is growing consensus around the idea of 'international corporate social responsibility' in response to the perception that there is a loss of corporate accountability, partly resulting from increasing globalisation. The idea rests on obligations that corporations should be liable to the societies in which they operate. International governmental organisations have expressed their interest in the need of all actors, including non-State actors, to observe the preservation of some fundamental principles, such as respect towards human rights and sustainable development.

67 [Emphasis added].

68 [Emphasis added]. 
Within the international investment law regime, the bulk of international obligations have fallen upon host States. By contrast, investors and home States have few, if any, international obligations. ${ }^{69}$ IIAs, with few exceptions, have been solely focused on creating rights for investors and legal obligations for states. A small number of recent IIAs carve out space for States to impose duties on the investor to comply with certain standards of conduct, such as national laws and internationally recognized Corporate Social Responsibility (CSR) standards, or to carry out good corporate governance practices in order to enhance the sustainable development dimension of CSR. ${ }^{70} \mathrm{Few}$ other investment treaties have incorporated States' efforts to prevent and combat corruption. For instance, the Colombia-Japan BIT (2011), in its Article 8, observes

Measures against Corruption: Each Contracting Party shall ensure that measures and efforts are undertaken to prevent and combat corruption regarding matters covered by this Agreement in accordance with its laws and regulations. ${ }^{71}$

However, the most significant level of regulation still falls upon States. On the one hand, home States have adopted a legal and regulatory system that might be used to ensure that multinational enterprises base and conform to certain standards of good corporate citizenship..$^{72}$ On the other hand, local laws of the host State exercise regulatory control towards foreign investments and investors, mostly when the investor is a multinational enterprise. Common examples are the regulation of domestic labour and antitrust laws.

Therefore, enterprises are thus expected to conduct themselves in accordance with proper standards, observing fundamental principles and to conduct investments in a reasonable manner. Investors are expected to respect and comply with the laws and regulations of both home and host States primarily because the high levels of mandatory regulation in the business sphere remains at the national level. ${ }^{73}$

UNCTAD sees corporate social responsibility as the quid pro quo for the protection of investors and investments under international investment treaties.74 Furthermore, UNCTAD's Investment Policy Framework contains some options that are designed to promote responsible investment by encouraging investors' compliance with universally recognized CSR standards.

\section{III.2.6. Investor-State Dispute Settlement Clauses}

ISDS clauses may limit the range of disputes that can be subject to arbitration, may preclude investors not in compliance with domestic laws to have recourse to arbitration or may enlarge the possibility of the host State to bring counterclaims in relation to investor unconscionable behaviour.

69 Muchlinski, supra nt 54, 84.

70 For example the investment agreement for the (Common Market for Eastern and Southern Africa) COMESA Common Investment Area (CCIA) imposes an obligation on investors to comply with local laws and the CARIFORUM-EC Economic Partnership Agreement incorporates anti-corruption obligations for investors.

71 [Emphasis added].

72 Muchlinski, supra nt 1, 84.

73 Ibid.

74 UNCTAD, The Social Responsibility of Transnational Corporations, New York and Geneva, 1999, at $<$ unctad.org/en/Docs/poiteiitm21_en.pdf> (accessed 13 April 2015). 
While States may be willing to renegotiate or provide further clarifications to the scope of investor-State dispute settlement provisions, several countries have decided to exclude ISDS clauses in their investment agreements.

An example of such is the China-Cuba BIT concluded in 1995 and modified by the parties in 2010. The ISDS provision was replaced with a more detailed one. ${ }^{75}$

Australia, New Zealand and India are examples of countries willing to exclude ISDS provisions from investment treaties. The Australia-Malaysia FTA concluded in 2012 does not contain such a provision, ${ }^{76}$ while India has publically stated that it is planning to exclude arbitration clauses from its BITs, which is currently under negotiation with the European Union, Australia, New Zealand and other countries.

Notwithstanding the intention of the parties to negotiate, renegotiate, revise and issue interpretative declarations on IIAs, with the aim of balancing public regulatory interests of States with private interests of investors, the effect and impact of their clauses cannot be assessed unless they are interpreted and applied by investment tribunals to concrete situations. It thus remains unclear whether these safeguards, exceptions, reservations and explanatory notes will be meaningful and effective to pursue SD objectives. Nevertheless, this should not discourage States from engaging in such a process.

Furthermore, even with investment treaties in their current form, sustainable development objectives can be achieved through the application of a SD oriented interpretation within the context of investor-State dispute settlement cases. This will be discussed in the next section.

\section{Systemic Interpretation of IIAs in Their Current Form: Achievement of Sustainable Development Objectives}

States' willingness to ensure consistency between their long-term sustainable development strategies and their existing investment treaties may be achieved through negotiation, renegotiation or revision of IIAs that incorporate sustainable development friendly provisions. Nonetheless, due to the fact that the vast majority of investment treaties negotiated over the last five decades by more than 176 countries $^{77}$ are currently in force, the task of reviewing and renegotiating IIAs with SD oriented provisions will be no mean feat.

Additionally, it is hard to achieve coherence between IIAs in their current form and the new generation of investment treaties that may be negotiated with SD friendly provisions. This is due to the fact that the potential application of the most favoured nation treatment clause may result in disregarding stricter provisions contained in these innovative treaties.

75 China-Cuba, Modification of The Agreement on the Promotion and Mutual Protection of Investments between the Government of the People's Republic of China and the Government of the Republic of Cuba, 3 April 2010, at <tfs.mofcom.gov.cn/article/h/bk/201003/20100306805846.shtml > (accessed 13 April 2015).

76 Malaysia-Australia Free Trade Agreement (FTA), 22 May 2012, at <www.miti.gov.my/cms/documentstorage/com.tms.cms.document.Document_7257fc06-c0a815732ce72ce7-76d00623/ MAFTA.pdf> (accessed 13 April 2015).

77 An example of ethical rules to be observed by arbitrators if parties so establish is the Code of Ethics for Arbitrators in Commercial Disputes formulated by a special joint committee of the American Bar Association (ABA) and the American Arbitration Association (AAA), revised in 2003 and effective since March 1, 2004. 
Furthermore, the effects and impact of sustainable development friendly provisions introduced in the new generation of investment treaties is yet to be assessed. It remains unclear how arbitral tribunals will interpret and apply these provisions.

Within this context, the form in which to achieve coherence between sustainable development objectives and investment treaties is to apply a SD oriented interpretation of IIAs. Such an interpretation would encourage States to pursue their SD long-term policies and would be useful - and necessary - to reduce the risks of future threats to global sustainability. The justifications for the adoption of such an interpretative approach are grounded in customary international law.

This section will first recall the role of investment tribunals and then will explain two interpretative approaches (the subjective dynamic approach and systemic integration of norms) that may be adopted by investment tribunals in order to foster SD.

\section{IV.1. The Role of Treaty-based Arbitral Tribunals}

The exercise of the arbitrators' authority and powers to hear and render a decision derives from the parties' consent. ${ }^{78}$ This is a primary consequence of the consensual nature of arbitration. ${ }^{79}$ Arbitrators will thereby conduct the arbitration and decide the dispute as submitted by the parties and in accordance with the legal and even ethical framework chosen by the parties as well as by the rules otherwise binding the tribunal. ${ }^{80}$ Thus, in general terms, the first and main duty of the tribunal is towards the parties: arbitrators' task is to decide the case at hand and to do their best effort to render an enforceable award. Contrary to national judges, arbitrators do not render 'justice' in the name of any State.

However, the scope of the tribunal's authority is also circumscribed by the governing law rules under which tribunals operate. There are several possible sources of arbitrators' powers which may act alternatively or cumulatively: international treaties between sovereign States (investment treaties, ICSID Convention), domestic laws, direct agreement between the investor and the State.

Against this background, this paper argues that tribunals' role is not limited to act on behalf of the disputing parties. Instead, tribunals' role also contributes to the development of international law. This is because the awards influence the behaviour of investors, States and - most importantly - the development of international investment law by concretising the scope and content of international standards of protection of foreign investors as well as generating new rules.

Though no formal doctrine of judicial precedent exists in international investment law, the decisions of arbitral tribunals may contribute as authoritative interpretations of the substantive obligations contained in IIAs, and may be seen as a subsidiary means for the determination of the rules of the international law on foreign investment.

Moreover, investment arbitration touches upon subject matters that raise public interest concerns and may affect the regulatory power of States. Arbitrators have the power to review and strike down State decisions, regulations, and national regulations. ${ }^{81}$

78 Notwithstanding the foregoing, once the arbitral tribunal is constituted and arbitrators are empowered, they have a high degree of autonomy and authority to decide procedural and substantive matters.

79 So true is that the parties' agreement empowers arbitrators, that parties may replace, revoke arbitrators at any time, and even put an end to the arbitration proceedings at any time.

80 An example of ethical rules is the ABA guidelines.

81 Choudhury, B, "Recapturing Public Power: Is Investment Arbitration's Engagement of the Public Interest Contributing to the Democratic Deficit?", 41 Vanderbilt Journal of Transnational Law (2008) 775. 
This has characterised investment arbitration as part of the evolving concept of global administrative law. ${ }^{82}$ As a scholar mentioned, arbitrators 'exercise interpretative powers over the content of investment treaty obligations and ... are the facto able to restrict even policy choices made by democratically elected legislators.' 83

For these reasons, investment arbitrators need to ensure coherence of the international investment regime within the context of public international law in general. They cannot, for instance, disregard or contradict international environmental agreements or human rights obligations.

\section{IV.2. Interpreting the Intention of the Parties as Reflected in the Treaty Text}

Tribunals, when interpreting international investment treaties, must have due regard to the intention of the parties having formulated them as expressed in the text. ${ }^{84}$ Tribunals' interpretation process will be guided by the customary and general principles of treaty interpretation which have been embodied in the Vienna Convention on the Law of Treaties (VCLT).

Articles 31-32 of the VCLT set forth the general rules of interpretation. In order to give effect to the intention of the contracting parties of a given treaty, tribunals need to look into the ordinary meaning of the words in their context and in the light of the treaty's object and purpose. Consideration of the treaty's object and purpose ensures the effectiveness of its terms (effet utile). ${ }^{85}$ The preamble plays an important role for the purpose of understanding and interpreting the context of the treaty.

Both the ICSID Convention and the vast majority of the IIAs acknowledge in their preamble the importance of FDI for the promotion of economic development. The ICSID Convention's primary aim was the promotion of economic development through the creation of a favourable investment climate that could be largely improved with the establishment of an effective system for settlement of disputes. According to the Executive Director's Report on the Convention

the creation of an institution designed to facilitate the settlement of disputes between States and foreign investors can be a major step toward promoting an atmosphere of mutual confidence and thus stimulating a larger flow of private international capital into those countries which wish to attract it. 86

82 Van Harten, G, Investment Treaty Arbitration and Public Law (Oxford University Press, New York, 2008); Van Harten, G and Loughlin, M, "Investment Treaty Arbitration as a Species of Global Administrative Law," 17(1) European Journal of International Law European Journal of International Law (2006) 121.

83 Schill, S, International Investment Law and Comparative Public Law (Oxford University Press, New York, 2010), 7.

84 As the ILC Commission observed 'the text must be presumed to be the authentic expression of the intentions of the parties': see Watts, A, ed, The International Law Commission 1949-1998: Volume Two: The Treaties (Clarendon Press, 2000), 687.

85 Villiger, M, "The Rules on Interpretation: Misgivings, Misunderstandings, Miscarriage? The 'Crucible' Intended by the International Law Commission" in Cannizzaro, E, ed, The Law of Treaties Beyond the Vienna Convention (Oxford University Press, New York, 2011), 110.

86 International Bank for Reconstruction and Development, Report of the Executive Directors on the Convention on the Settlement of Investment Disputes between States and Nationals of other States, 18 March 1965, at <icsid.worldbank.org/ICSID/StaticFiles/basicdoc/partB.htm> (accessed 13 April 2015), para 9. 
Likewise, in general terms, IIAs contain statements incorporated in the preamble which acknowledge the importance of promoting foreign investment and the flow of capital. Indeed, foreign investments are perceived to enhance the economic cooperation to the mutual benefit of signatory parties and to intensify and expand economic activities, prosperity and development of both parties. ${ }^{87}$

Within this context, it seems that the idea of concluding IIAs is neither to attract all kind of foreign capital nor at all costs; but to foster individual business initiative because it will support growth and prosperity of signatory countries. The ultimate rationale behind this is that the raison d'etre of States is to provide wealth to their inhabitants. In a famous statement, Aristotle asserted that the State 'comes to be for the sake of living, but it remains in existence for the sake of living well'. 88

It is thus necessary to adopt a rational interpretation of IIAs, taking into account the real intention of States when concluding those agreements. A balanced approach means that IIAs cannot protect foreign transactions that are detrimental to the development of any of the signatory countries. To conclude otherwise, would be contrary to the intention of the contracting parties and therefore would lead to an unreasonable interpretation.

\section{IV.3. Systemic Integration of Norms in Treaty Interpretation}

Safeguarding the unity and coherence of international law has been a concern addressed by the International Law Commission. In 2006 a report was issued seeking to provide solutions to the problems of coherence in international law which resulted from the 'emergence of the new and special types of law, 'self-contained regimes' and geographically or functionally limited treaty-systems' ${ }^{89}$ Amongst other conclusions, the ILC suggested that rules, principles and norms of international law viewed as a legal system act in relation to, and to be interpreted against the background of other rules and principles. Equally, the Working Group stated that certain types of general law, such as jus cogens, must not be derogated from by the lex specialis. ${ }^{90}$

The ILC conclusions are interrelated with Article 31(3)(c) of the VCLT. According to this provision, '[e]very treaty provision must be read not only in its own context, but in the wider context of general international law, whether conventional or customary.' ${ }^{91}$ In this sense, both, conventional and customary international law rules existing at the time of the conclusion of the treaty as well as subsequently, may be relevant for interpretative purposes. ${ }^{92}$ This article envisages treaty interpretation against the whole background of international law, including general, regional or local customary rules as well as rules contained in bilateral or multilateral treaties. ${ }^{93}$ This general principle for treaty

87 Random investment treaties were analysed and all of them had in their preamble a reference to economic development, economic cooperation, prosperity or a similar wording.

88 Korab-Karpowicz, WJ, On the History of Political Philosophy: Great Political Thinkers from Thucydides to Locke (Pearson, New York, 2012), 39.

89 International Law Commission, REPORT: Fragmentation of International Law: Difficulties Arising from the Diversification and Expansion of International Law, 58th session (2006), A/CN4/L682, para 15.

$90 \quad I d$, paras 251.1 and 251.10.

91 Sir Ian McTaggart Sinclair, The Vienna Convention on the Law of Treaties (Manchester University Press ND, 1984), 139.

92 Report of the International Law Commission, Fifty-eighth session (1 May-9 June and 3 July-11 August 2006) General Assembly Official Records, Sixty-first session, Supplement No 10 (A/61/10), 415, para 22. See also Bekker, PHF, Dolzer, R, and Waibel, M, Making Transnational Law Work in the Global Economy: Essays in Honour of Detlev Vagts (Cambridge University Press, 2010), 348-349.

93 Villiger, supra nt 82,111. 
interpretation is known as systemic integration of norms within the international legal system. ${ }^{94}$

International courts and tribunals have already dealt with the principle of systemic integration. It was in the Gab'ikovo-Nagymaros case that the ICJ observed the relevance of environmental norms in the interpretation of existing treaties. ${ }^{95}$ Likewise, in the Oil Platforms case the Court acknowledged that the treaty at hand was 'intended to operate wholly independently of the relevant rules of international law' and therefore the application of the relevant rules of international law (Article 31(3)(c) of the VCLT) relating to this question formed an integral part of the task of interpretation entrusted to the Court. 96

In the Mox Plant case, arbitral tribunals were invited to consider several environmental protection treaties. ${ }^{97}$ Also in the Shrimp-Turtle case before the WTO Dispute Settlement Understanding, the Appellate Body looked beyond trade rules and made extensive reference to international environmental agreements. ${ }^{98}$

Investment tribunals have also acknowledged, although vaguely, this principle. In Asian Agricultural Products Ltd. v Sri Lanka the tribunal considered that the investment treaty in question was not a

self-contained closed legal system limited to provide for substantive material rules of direct applicability, but it has to be envisaged within a wider juridical context in which rules from other sources are integrated through implied incorporation methods, or by direct reference to certain supplementary rules, whether of international lay character or of domestic law nature. 99

Similarly, in Metalclad $v$ Mexico, the tribunal agreed that treaty interpretation shall include any relevant rules of international law applicable in the relations between the parties.100 However, the tribunal failed to state those relevant rules. In Ioannis Kardassopoulos $v$ Georgia the tribunal considered that the relevant rules include those of general customary international law. ${ }^{101}$

In the same regard, the tribunal in RosInvestCo v Russian Federation emphasised that the relevant rules applicable in the relations between the parties must be taken as a reference to rules of international law that 'condition the performance of the specific rights and obligations stipulated in the treaty - or else it would amount to a general licence to

94 Campbell, M, "The Principle of Systemic Integration and Article 31(3)(C) of the Vienna Convention", 54(2) International \& Comparative Law Quarterly (2005) 279.

95 International Court of Justice (ICJ), Gabčíkovo-Nagymaros Project (Hungary v Slovakia), ICJ Reports 1997, 25 September 1997, 7, para 111.

96 ICJ, Oil Platforms Case (Iran v United States of America), ICJ Reports 2003, 6 November 2003, para 41.

97 International Tribunal on the Law of the Sea (ITLOS), The MOX Plant Case (Ireland $v$ United Kingdom), Provisional Measures, Order of 3 December 2001, (2002) 41 ILM 405, 413.

98 World Trade Organization Dispute Settlement Body, US Import Prohibition of Certain Shrimps and Shrimps Products, Appellate Body Report, WT/DS58/AB/R, 12 October 1998.

99 Asian Agricultural Products Ltd v Sri Lanka, ICSID Case No ARB/87/3, Final Award, 27 June 1990, para 21.

100 Metalclad Corporation v United Mexican States, ICSID Case No ARB(AF)/97/1, Award, 30 August 2000, para 70.

101 Ioannis Kardassopoulos v Georgia, ICSID Case No ARB/05/18, Decision on Jurisdiction, 6 July 2007, para 208. 
override the treaty terms that would be quite incompatible with the general spirit of the Vienna Convention as a whole.' 102

The foregoing examples suggest that investment tribunals may incorporate in their legal process of interpretation other treaties, customary rules, or general principles of law that may be of relevance when assessing a particular dispute. In doing so, consideration to environmental and human rights norms will be given and SD is thus enhanced.

In more concrete terms, systemic integration could play a relevant role when asserting the scope of open-ended terms in investment treaties as well as when standards of treatment and protection require being weighed against legitimate regulatory measures adopted with the purpose of complying with environmental or human rights norms. In particular, IIA clauses on fair and equitable treatment, full protection and security or expropriation must be interpreted in light of relevant rules, principles and treaties applicable in the relations between the contracting parties. Furthermore, systemic integration may be applicable for balancing investment protection with public policy objectives.

As stated by the ILC, systemic integration should apply in the presumption that '[in] entering into treaty obligations, the parties do not intend to act inconsistently with generally recognized principles of international law.' 103

Systemic integration is thus a relevant tool for incorporating environmental protection norms, human rights and other relevant rules in investment treaty disputes. This integration not only safeguards the coherence of international law but also allows taking into account SD objectives established in those relevant instruments.

\section{Conclusion}

In order to foster sustainable development through the application of dynamic social and environmental norms and regulations, States need to have enough domestic policy space to regulate. Constraints on this policy space may impact the achievement of SD objectives, and investment treaties may be perceived as a limitation.

Investment treaty provisions are usually drafted in vague and broad terms and they lack strong references to sustainable development. This has given wide interpretative discretion to investment tribunals when balancing the protection of investors' rights with the interests of the host State. Several investment treaty provisions such as the definition of 'investment' and 'investor' as well as provisions regarding the treatment of investors have been interpreted in favour of investment protection without taking into account broader considerations which are, ultimately, closely connected to a countries' sustainable development policies.

States' reactions towards these broad interpretations have been diverse. Some States are trying to withdraw from the international investment regime while others are willing to shift their international investment policy towards the new generation of investment agreements. This new generation of IIAs is characterised by drafting treaty provisions that foster sustainable development though innovative features.

With the aim to assist countries in the drafting of this new generation of investment agreements UNCTAD has developed its Investment Policy Framework for Sustainable Development. Furthermore, IPFSD's core principles for investment policymaking for

102 RosInvestCo UK Ltd v Russian Federation SCC Case No V079/2005, Award on Jurisdiction, 1 October 2007, para 39.

103 Report of the International Law Commission, supra nt 89, para 19 [emphasis added]. 
sustainable development may serve as additional guidance for investment tribunals' interpretative approaches.

Despite the willingness to shift towards new policies, States may face several constraints. The renegotiation and revision of existing agreements may be in practice very difficult. Furthermore, the application of investment agreements with SD features may be limited, ie through the application of the most favoured nation treatment clause.

Within this context, investment tribunals play a fundamental role in integrating sustainable development considerations into investment disputes. Investment tribunals may resort to the Vienna Convention on the Law of Treaties in order to adopt contextual, dynamic and systemic interpretative approaches in favour of the notion that investment agreements ought to pursue the countries' overall development, going beyond the mere achievement of economic goals. Instead, investment should now be viewed as sustainable, responsible and to be protected. Investment should forthwith incorporate the concepts of sustainability and responsibility. 